\title{
PEMAHAMAN DAN MINAT MASYARAKAT PETANI LADA BANGKA BELITUNG TERHADAP PENERAPAN SISTEM RESI GUDANG
}

\author{
Rahmat Ilyas' ${ }^{1}$, Alwan Sobari ${ }^{2}$ \\ 1,2,IAIN Syaikh Abdurrahman Siddik Bangka Belitung \\ rahmatilyas@gmail.com
}

Received: 05/08/2020, Accepted: 07/08/2020, DOI: 10.32923/sci.v5i1.1342

\begin{abstract}
One of the challenges of winning global competition is by issuing new instruments in the field of trade and managing national inventories, so that the prices of goods offered can compete in the global market. The trade finance system must be accessible at all times by every entrepreneur, mostly small entrepreneurs, and small farmers, who have been hampered by capital difficulties and credit borrowing difficulties. SRG is one of the important and effective instruments in the trade finance system. SRG can facilitate credit for the business world with inventory collateral or goods stored in warehouses. SRG is also useful in stabilizing market prices by facilitating sales that can be done throughout the year. This study tries to see and examine where the level of understanding and interest of the community about farmers in the Pacific Islands against SRG that has developed at this time. He made the community of Belitung Bangka pepper farmers as one of the attractions because Bangka Belitung farmers are farmers with a fairly large pepper fact. The research method used in this study is a quantitative method. The population taken in this study is the farming community in the Bangka Belitung Islands province, the number of samples in the study amounted to 397 respondents. The technique or method of collecting data used in this study is in the form of a Questionnaire. The results of this study indicate that Bangka Belitung pepper farmer research on the warehouse receipt system is classified as low, this is seen by the results of respondents' answers 70.3\% (279 respondents) respondents are relatively low, 27.5\% (109 respondents) moderate understanding level and $2.3 \%$ (9 respondents) respondents included in the high category. Likewise, with the interest of Bangka Belitung pepper farmers to the warehouse receipt system is also relatively low, from 397 respondents as many as $58.7 \%$ (233 respondents) respondents were classified as low, 34.5\% (137 respondents) the level of interest was moderate and $6.8 \%$ (27 respondent) respondents who are in the category of high interest.
\end{abstract}

\section{Keywords: Community, Pepper Farmers, Warehouse Receipts}

\section{Introduction}

Salah satu upaya menghadapi persaingan global adalah dengan menerbitkan instrumen baru dalam bidang pembiayaan perdagangan dan pengelolaan stok nasional, sehingga harga barang yang ditawarkan dapat bersaing di pasar global. Sistem pembiayaan perdagangan tersebut harus dapat diakses setiap waktu oleh setiap pelaku usaha, terutama pengusaha kecil dan petani kecil, yang selama ini masih terbentur masalah kesulitan permodalan dan keterbatasan jaminan kredit.

Permasalahan umum pertanian di Indonesia adalah jatuhnya harga pada saat musim panen raya. Para petani tidak dapat menyimpan hasil panen lebih lama karena sudah kehabisan biaya dan tidak punya gudang yang memadai. Kondisi ini dimanfaatkan para tengkulak dan rentenir untuk mengambil untung besar, para tengkulak dan pengelola gudang besar milik BUMN atau swasta. Permasalahan tersebut kemudian coba diatasi pemerintah melalui pendirian Pasar Lelang Komoditas, Kredit Usaha Rakyat, dan Sistem Resi Gudang atau Werehouse Receipt System (selanjutnya disebut dengan SRG). Dengan adanya SRG, petani tidak terlalu terburu-buru menjual hasil panen, sebab mereka masih dapat menyimpan hasil panen di gudang terakreditasi, dan dapat menjadikan dokumen resi gudang yang dimilikinya sebagai jaminan kredit di bank. Pada saat harga pasaran telah membaik, petani dapat menjual barang dan melunasi kredit, serta mendapat sisa uang hasil penjualan.

SRG merupakan salah satu instrumen penting dan efektif dalam sistem pembiayaan perdagangan. SRG dapat memfasilitasi pemberian kredit bagi dunia usaha dengan agunan inventori atau barang yang disimpan di 
gudang. SRG juga bermanfaat dalam menstabilkan harga pasar dengan memfasilitasi cara penjualan yang dapat dilakukan sepanjang tahun.

SRG diterapkan untuk menyimpan hasil pertanian sehingga dapat menjaga stok pangan yang akan berdampak pada kestabilan harga. Selain itu, SRG juga dapat meningkatkan kredit/pembiayaan kepada petani, poktan, gapoktan, koperasi dan pelaku UMKM karena sistem ini berlaku sebagai alternatif pembiayaan dari bank dengan memanfaatkan Resi Gudang sebagai agunan. Berdasarkan Krishnamurti (2009), instrumen resi gudang dapat dipergunakan untuk mengatasi masalah kelebihan nilaian komoditas tertentu pada bulan-bulan tertentu pada masa panen. Selanjutnya pembiayaan yang diperoleh dari skema tersebut akan disalurkan kembali untuk para petani. Sehingga, SRG tidak hanya berperan sebagai instrumen pemasaran dalam konteks kepentingan nasional tetapi juga dapat menjadi pendukung kebijakan stabilitas harga dan ketersediaan pangan.

Implementasi SRG diharapkan dapat memberikan dampak yang cukup besar bagi perkembangan perekonomian baik daerah maupun nasional. Dampak yang nyata dapat dirasakan adalah adanya peningkatan pendapatan petani melalui harga jual yang lebih baik, tumbuhnya industri pergudangan di daerah, serta berkembangnya lembaga-lembaga pembiayaan. Disamping itu implementasi SRG juga akan memberikan dampak tidak langsung seperti tumbuhnya pola kemandirian usaha dan enterpreneurship pada petani dan pelaku usaha.

Implementasi SRG di Indonesia dimulai sejak ditetapkannya UU No.9 Tahun 2006 kemudian diubah oleh UU No.9 Tahun 2011. Dalam perkembangannya, implementasi SRG ternyata tidak sebaik yang diharapkan. Saat ini jumlah gudang SRG sebanyak 168 gudang, 120 gudang adalah milik pemerintah dan 48 gudang milik swasta. Dari total 120 gudang milik pemerintah sebanyak 80 gudang sudah memperoleh izin dari Bappebti. Dari 80 gudang yang telah memperoleh izin dari Bappebti, sebayak 65 gudang telah menerbitkan Resi Gudang atau sebesar $81 \%$ yang mayoritas adalah komoditas pangan yaitu gabah, beras dan jagung (Bappebti, 2016).

Komoditas pertanian yang dapat disimpan dalam gudang dalam rangka penyelenggaraan SRG adalah sebanyak sembilan komoditas, yaitu: gabah, beras, jagung, kopi, kakao, lada, karet, rumput laut dan rotan. Hal ini sesuai dengan Peraturan Menteri Perdagangan No. 37/M-DAG/PER/11/2011 tahun 2011 tentang Barang yang dapat disimpan di gudang dalam penyelenggaraan SRG.

Provinsi kepulauan Bangka belitung merupakan salah satu wilayah yang mempunyai penghasilan komoditas lada yang cukup besar. Data badan pusat statistik (BPS) menyebutkan bahwa perkembangan penghasilan lada dari 2014-2016 sebagaimana dalam tabel berikut:

Tabel. I

Perkembangan Penghasilan Lada Provinsi Bangka Belitung

\begin{tabular}{|l|c|c|c|}
\hline \multirow{2}{*}{ Kabupaten/kota } & \multicolumn{3}{c|}{ Produksi Lada (Ton) } \\
\cline { 2 - 4 } & $\mathbf{2 0 1 6}$ & $\mathbf{2 0 1 5}$ & $\mathbf{2 0 1 4}$ \\
\hline Bangka & 10 & 9 & 9 \\
\hline Belitung & 11 & 7 & 7 \\
\hline Bangka Barat & 6 & 4 & 4 \\
\hline Bangka Tengah & 12 & 7 & 7 \\
\hline Bangka Selatan & 9 & 7 & 7 \\
\hline Belitung Timur & 14 & 7 & 7 \\
\hline Pangkalpinang & 0 & - & - \\
\hline Jumlah & 62 & 41 & 41 \\
\hline
\end{tabular}

Sumber: BPS Kep. Bangka Belitung

Hadirnya SRG diyakini memiliki banyak manfaat, namun sejak diimplementasi pada tahun 2006 hingga saat ini, SRG belum termanfaatkan secara optimal. Pemanfaatan SRG yang kurang optimal disebabkan adanya kendala yang harus dihadapi dalam implementasi SRG seperti kurangnya pemahaman masyarakat terhadap mekanisme SRG, kurangnya komitmen pemerintah daerah dalam pengembangan SRG, terbatasnya pengelola gudang yang memiliki kecukupan modal operasional, dan terbatasnya lembaga Penguji Mutu Komoditi tertentu di beberapa daerah (Bappebti, 2015). Untuk mengatasi kendala ini maka dibutuhkan suatu inovasi untuk pengembangan SRG guna mendorong optimalisasi pemanfaatan SRG.

Meskipun memiliki banyak manfaat, namun sejak diimplementasi pada tahun 2006 hingga saat ini, SRG 
belum termanfaatkan secara optimal. Hal ini dapat dilihat dari kapasitas penyimpanan di dalam gudang SRG yang belum optimal. Rata-rata kapasitas penyimpanan kurang dari 50\% kapasitas gudang SRG (1.000 - 1.500 ton). Selain itu, masih terdapat gudang SRG yang belum beroperasi sejak didirikan (25 gudang dari 117 gudang).

Pemanfaatan SRG yang kurang optimal disebabkan adanya kendala yang harus dihadapi dalam implementasi SRG seperti kurangnya pemahaman masyarakat terhadap mekanisme SRG, kurangnya komitmen pemerintah daerah dalam pengembangan SRG, terbatasnya pengelola gudang yang memiliki kecukupan modal operasional, dan terbatasnya lembaga Penguji Mutu Komoditi tertentu di beberapa daerah (Bappebti, 2015). Untuk mengatasi kendala ini maka dibutuhkan suatu inovasi untuk pengembangan SRG guna mendorong optimalisasi pemanfaatan SRG. Untuk itu Badan Pengawas Perdagangan Berjangka Komoditi (Bappebti) selaku unit kerja yang bertanggung jawab terhadap pelaksanaan SRG menyusun strategi pengembangan SRG antara lain dengan mengembangkan model bisnis SRG integratif (pra-Resi gudang) hingga hilir (termasuk jaringan logistik dan pemasarannya) melalui pemanfaatan pasar lelang.

Penelitian ini mencoba melihat dan mengkaji sejauh mana tingkat pemahaman serta minat masyarakat khususnya petani lada di bangka belitung teradap SRG yang sudah berkembang saat ini. Dijadikannya masyarakat petani lada bangka Belitung sebagai salah objek penelitan karena petani Bangka Belitung merupakan petani dengan penghasilan komoditas lada yang cukup besar.

\section{Method of Research}

a. Jenis Penelitian

Jenis penelitian ini adalah penelitian deskriptif kuantitatif. sifat dari penelitian ini adalah deskriptif yaitu penelitian yang berusaha untuk menuturkan pemecahan masalah yang ada sekarang berdasarkan data-data, menganalisis dan menginterpretasi. Bisa bersifat komperatif dan korelatif.

\section{b. Lokasi Penelitian}

Adapun lokasi Penelitian ini dilaksanakan di Provinsi Kepulauan Bangka Belitung yang di khususkan pada masyarakat Petani lada pada masing-masing kabupaten yang ada di Provinsi Kepulauan Bangka Belitung.

\section{c. Populasi dan Sampel Penelitian}

Populasi adalah wilayah generalisasi yang terdiri atas objek/subyek yang mempunyai kualitas dan karakteristik tertentu yang ditetapkan oleh peneliti untuk dipelajari dan kemudian ditarik kesimpulan . Adapun wilayah yang dijadikan sebagai populasi dalam penelitian ini adalah seluruh petani lada dari 6 kabupaten yang ada di provinsi Kepulauan Bangka Belitung. Untuk mengetahui jumlah populasi dari masingmasing kabupaten tersebut maka akan terlihat seperti pada tabel berikut:

Penentuan jumlah populasi dalam penelitian ini dikategorikan berdasarkan data yang diperoleh dari Statistik Perkebunan Indonesia 2015-2017 Direktorat Jenderal Perkebunan tentang jumlah petani lada yang provinsi Kepulauan Bangka Belitung. Adapun jumlah populasi dalam penelitian ini adalah sebanyak 56.940 petani. dalam penelitian ini mengingat jumlah petani lada yang akan dijadikan sebagai populasi dalam penelitian ini adalah sebesar 56.940, dengan demikian jumlah sampel yang diperoleh dengan menggunakan rumus slovin dengan nilai kritis $5 \%$ maka jumlah sampel yang dibutuhkan adalah sebanyak 397,20 dan dibulatkan menjadi 397 sampel.

\section{d. Variabel Penelitian}

Variabel adalah gejala yang bervariasi, sedangkan gejala adalah objek penelitian. Jadi variabel adalah objek penelitian yang bervariasi. Lebih lanjut Arikunto menjelaskan bahwa "variabel adalah objek penelitian atau apa yang menjadi titik perhatian suatu penelitian". Adapun yang menjadi variabel dalam penelitian ini yaitu pemahaman (X1), Minat (X2) penerapan sistem resi gudang (Y).

\section{e. Teknik Pengumpulan Data}

Adapun teknik atau cara pengumpulan data yang digunakan dalam penelitian ini adalah:

1) Angket atau Kuesioner

Kuesioner adalah sejumlah pertanyaan tertulis yang digunakan untuk memeperoleh informasi dari responden dalam arti laporan pribadinya, atau hal-hal yang ia ketahui. Sedangkan bentuk kuesioner yang akan dilaksanakan yaitu dengan bentuk rating-scale (skala bertingkat), yaitu sebuah pernyataan diikuti oleh kolomkolom yang menunjukkan tingkatan-tingkatan, misalnya mulai dari sangat paham sampai ke sangat tidak paham. Kuesioner yang merupakan alat pengumpulan data penelitian diberikan kepada responden secara 
langsung.

2) Observasi

Observasi adalah alat pengumpulan data yang dilakukan dengan cara mengamati dan mencatat secara sistematik gejala-gejala yang diselidiki. Dalam penelitian ini penulis menggunakan metode observasi non partisipan dimana peneliti tidak ikut terlibat langsung dalam penanganan masalah yang sedang diteliti. Dalam penelitian ini, peneliti melaksanakan observasi untuk mengamati tentang karakteristik demografi masyarakat Petani lada di Provinsi Kepulauan Bangka Belitung.

3) Dokumentasi

Dokumentasi digunakan untuk mengumpulkan data berupa data-data tertulis yang mengandung keterangan dan penjelasan serta pemikiran fenomena yang masih aktual dan sesuai dengan masalah penelitian. Dokumentasi berproses dan berawal dari menghimpun dokumen, memilihi-milih dokumen sesuai dengan tujuan penelitian, mencatat dan menerangkan, menafsirkan dan menghubung-hubungkan dengan fenomena lain. Dalam hal ini peneliti berupaya memperoleh data yang bersifat dokumentasi dari pihak-pihak yang terkait khususnya berkaitan dengan lokasi penelitian, kependudukan dan karakteristik demografi masyarakat petani Bangka Belitung.

4) Teknis Analisa Data

Adapun teknik analisis data yang dilakukan dalam penelitian ini dengan terlebih dahulu menggunakan uji Uji Asumsi klasik yang terdiri dari, Uji Normalitas, Uji Multikolinearitas, Uji Heteroskedastisitas. Selanjutnya dilakukan uji hipotesis melalui Uji Koefisien Determinasi (Adjusted R2), Uji Simultan (Uji F), Uji Signifikan Parsial (Uji T).

\section{Pembahasan}

\section{1) Pemahaman dan minat Masyarakat Petani Bangka Belitung terhadap Sistem Resi Gudang.}

Resi Gudang adalah surat atau dokumen bukti kepemilikan atas barang yang disimpan di gudang Sistem Resi Gudang (SRG). Resi Gudang dapat digunakan sebagai angunan atau jaminan untuk memperoleh pinjaman pinjaman dana atau kredit dari lembaga keuangan, baik bank maupun non bank. Sebab Resi Gudang dijamin dengan komoditi yang selalu dijaga dan dikelola oleh Pengelola Gudang yang terakreditasi (memiliki izin dari Bappebti).

Sistem Resi Gudang (SRG) adalah kegiatan-kegiatan yang berkaitan dengan penerbitan, pengalihan, penjaminan dan penyelasaian transaksi Resi Gudang. SRG merupakan salah satu instrumen penting dan efektif dalam sistem pembiayaan perdagangan, karena dapat memfasilitasi pemberian kredit bagi petani dan pelaku usaha dengan agunan komoditi yang disimpan di gudang SRG.

Resi gudang atau disebut juga warehouse receipt system (WRS) adalah dokumen bukti kepemilikan barang yang disimpan di suatu gudang yang diterbitkan oleh pengelola gudang (UU No 9, 2011). Resi Gudang merupakan sekuriti yang menjadi instrumen perdagangan serta merupakan bagian dari sistem pemasaran dan sistem keuangan di banyak negara (Wikipedia, 2009). Dalam konteks ini, "gudang" memiliki pe-ngertian bermacam-macam, tergantung komoditas yang disimpan, mulai dari coklat, kopi, beras, hingga minyak sawit. Resi gudang ini nantinya bisa digunakan sebagai jaminan atas kredit dari perbankan.

Berdasarkan hasil penelitian yang telah dilakukan pada masyarakat petani lada di provinsi Kepulauan Bangka Belitung terkait dengan pemahaman dan minat masyarakat peatani lada terhadap sistem resi gudang yang ada di Bangka Belitung sebagaimana dalam grafik berikut ini;

Grafik. 1

Kategorisasi Variabel Pemahaman

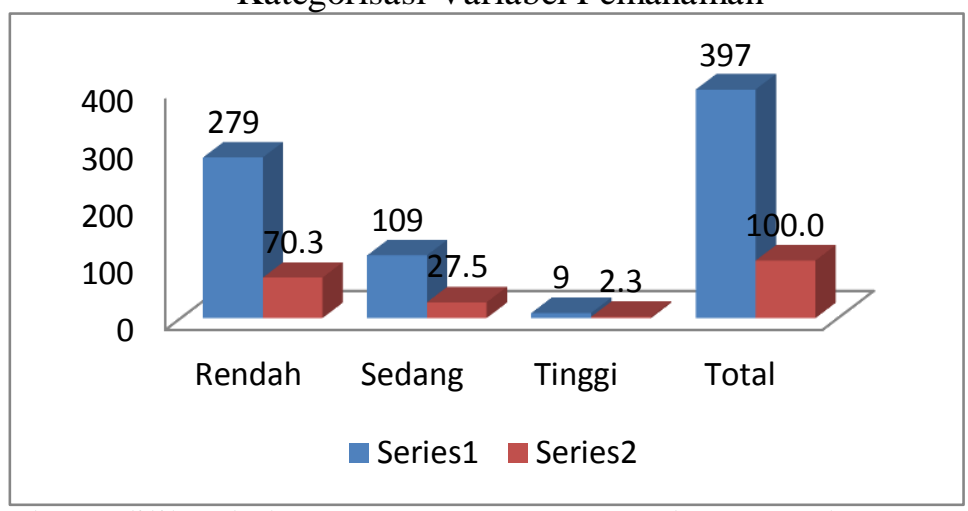

Dari grafik diatas dapat dilihat bahwa 70,3 \% (279 responden) pemahaman masyarakat petani lada di Bangka belitung tergolong rendah, 27,5\% (109 responden) tingkat pemahamannya sedang dan 2,3\% (9 
responden) responden yang masuk kategori tinggi tentang pemahaman terhadap resi gudang di Bangka Belitung.

Penelitian ini menunjukkan bahwa secara umum hasil dari jawaban responden terkait dengan pemahaman masyarakat petani lada yang ada di provinsi Kepulauan Bangka Belitung terhadap resi gudang masih tergolong rendah. Data menunjukkan bahwa dari 397 responden yang berada di provinsi Bangka Belitung terdapat 279 responde atau sebbesar 70,3\% masyarakat petani lada Bangka Belitung mengatakan bahwa mereka belum paham tentang resi gudang yang sudah ada di Bangka Belitung.

Banyaknya masyarakat petani lada Bangka Belitung yang tidak paham terhadap resi gudang dikarenakan beberapa hal diantaranya, keberadaan atau lokasi tempat resi gudang yang sangat jauh dari masing-masing rumah atau tempat petani lada berada, dan juga disebabkan terbatasnya jumlah gudang yang tersedia di provinsi Kepulauan Bangka Belitung sehingga menyebabkan masih banyak masyarakat yang kesulitan untuk mengakses inforamsi yang terkait dengan resi gudang tersebut.

Sedangkan kalau dilihat dari tingkat minat masyarakat petani lada Bangka belitung terhadap resi gudang sebagaimana dalam grafik berikut ini:

Grafik. 2

Kategorisasi Variabel Minat

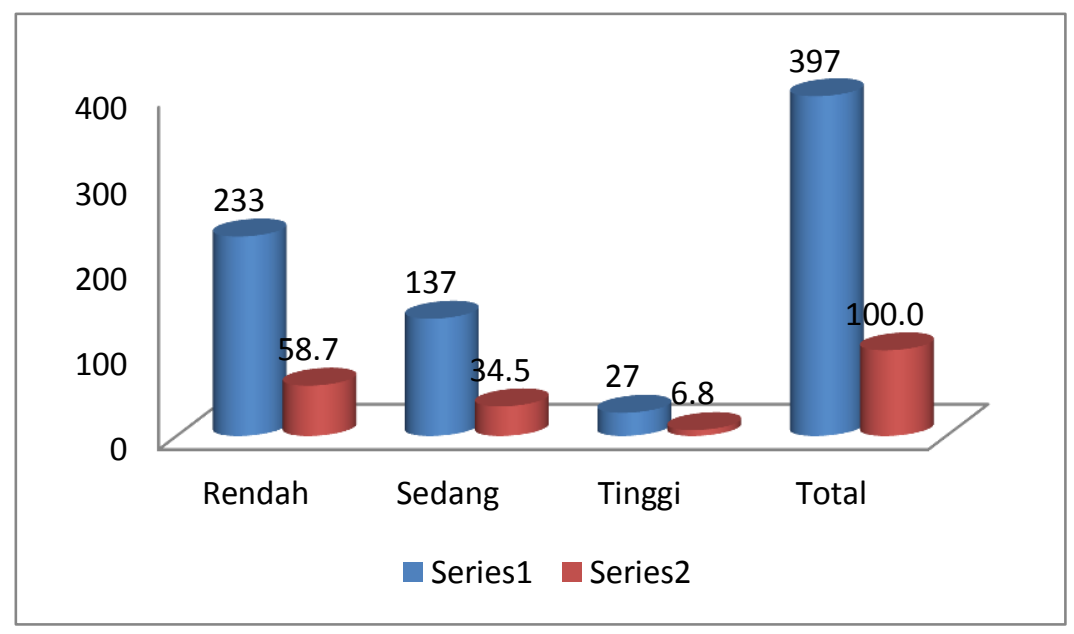

Dari grafik diatas dapat dilihat bahwa 58,7 \% (233) responden minat masyarakat petani lada di Bangka belitung tergolong rendah, 34,5\% (137) tingkat minatnya sedang dan 6,8\% (27) responden yang masuk kategori tinggi tentang minat terhadap resi gudang di Bangka Belitung.

Dari data diatas dapat di ketahui bahwa secara umum masyarakat petani lada yang berada di provinsi kepulauan Bangka Belitung berdasarkan hasil responden dinyatakan kurang berminat terhadap penerapan sistem resi gudang yang sudah ada sekarang. Dari 397 responden yang tersebar di provinsi Bangka Belitung hanya 27 responden atau sebesar 6,8\% yang menyatakan berminat terhadap resi gudang yang ada sekarang, dan 233 responden atau sebesar 58,7\% menyatakan kurang berminat atau masuk kategori rendah terhadap resi gudang.

Rendahnya minat masyarakat petani lada Bangka Belitung terhadap resi gudang yang ada disebabkan beberapa hal diantaranya rendahnya pemahaman masyarakat petani lada Bangka Belitung terhadap resi gudang itu sendiri, selain itu juga karena faktor lokasi yang jauh dan sulit untuk menjangkau keberadaan resi gudang, karena hingga saat ini lokasi gudang yang ada di Bangka Belitung masih sangat terbatas dan belum ada di setiap kabupaten di provinsi Bangka Belitung.

Hasil penelitian ini sangat sejalan dengan hasil penelitian yang dilakukakan oleh Anggun Novita Sari dan Yuliawati dengan judul Faktor yang Mempengaruhi Respon Petani Garam Tentang Sistem Resi Gudang Di Desa Raci Kecamatan Batangan hasil penelitian menunjukkan bahwa Faktor-faktor yang mempengaruhi respon petani garam tentang SRG adalah tingkat pendidikan, persepsi mengenai SRG, dan peran PPL sedangkan faktor yang tidak berpengaruh adalah umur, luas lahan, dan motivasi. ${ }^{1}$

Menurut hasil penelitian yang dilakukan oleh Novita sari dan Yuliawati bahwa faktor yang

\footnotetext{
${ }^{1}$ Anggun Novita Sari dan Yuliawati, Faktor Yang Mempengaruhi Respon Petani Garam Tentang Sistem Resi Gudang Di Desa Raci Kecamatan Batangan, Journal on Socio-Economics of Agriculture and Agribusiness Vol.13 No.1, 28 Februari 2019, https://ojs.unud.ac.id/index.php/soca
} 
mempengaruhi respon petani garam tertang SRG salah satunya adalah persepi mengenai SRG, sedangkan dalam penelitian ini kurangnya minat masyarakat terhadap resi gudang adalah karena rendahnya pemahaman atau informasi petani lada terhadap resi gudang itu sendiri.

\section{2) Pengaruh antara tingkat pemahaman dan minat masyarakat Petani Bangka Belitung terhadap Sistem Resi Gudang}

Sektor pertanian merupakan sektor utama yang berperan penting pada perekonomian nasional dalam menyerap tenaga kerja, sumber pertumbuhan ekonomi, dan penyumbang devisa. Di samping itu, sektor pertanian juga menggerakkan sektor lain dalam perekonomian nasional. Bertitik tolak dari kondisi tersebut, perhatian akan ketersediaan data sektor pertanian yang lengkap, akurat, dan terkini sangat dibutuhkan sebagai acuan bagi pemerintah maupun para pemangku kepentingan (stakeholders) dalam perencanaan dan perumusan kebijakan. $^{2}$

Perkembangan pelaksanaan SRG pada masa awal diimplementasikan terbilang cukup lambat. Menurut Suhendro (2008) yang dikutip Ashari, sejak UU SRG diperkenalkan pada tahun 2007 sebagai sebuah alternatif pembiayaan keuangan bagi para petani, ternyata penetrasinya masih terbilang rendah. Hal ini dapat dilihat berdasarkan proyek percontohan sistem resi gudang di empat daerah, yaitu di Indramayu, Banyumas, Jombang untuk komoditas gabah dan Gowa untuk komoditas jagung. Dari proyek percontohan tersebut, hanya 305 ton komoditas dikeluarkan sebagai surat berharga/resi gudang yang mencakup 15 resi dengan nilai kurang lebih Rp 1 miliar. $^{3}$

Berdasarkan hasil penelitian yang telah dilakukan menunjukkan bahwa tingkat pemahaman dan minat masyarakat petani lada Bangka Belitung terhadap resi gudang sebagaimana dalam tabel berikut ini:

Tabel. II

Uji Parsial (Uji T)

Coefficients $^{\mathrm{a}}$

\begin{tabular}{|c|c|c|c|c|c|c|}
\hline \multirow{2}{*}{\multicolumn{2}{|c|}{ Model }} & \multicolumn{2}{|c|}{$\begin{array}{l}\text { Unstandardized } \\
\text { Coefficients }\end{array}$} & \multirow{2}{*}{$\begin{array}{c}\text { Standardized } \\
\text { Coefficients } \\
\text { Beta }\end{array}$} & \multirow[b]{2}{*}{$\mathrm{t}$} & \multirow[b]{2}{*}{ Sig. } \\
\hline & & B & $\begin{array}{l}\text { Std. } \\
\text { Error }\end{array}$ & & & \\
\hline \multirow[t]{3}{*}{1} & (Constant) & 3,021 & 1,105 & & 2,735 & ,007 \\
\hline & Pemahaman & , 156 & ,020 & ,356 & 7,881 &, 000 \\
\hline & Minat & ,354 & ,036 & ,443 & 9,802 & ,000 \\
\hline
\end{tabular}

Dependent Variable: Sistem_Resi_Gudang

Hasil penelitian yang dilakukan terhadap petani lada Bangka Belitung menunjukkan bahwa terdapat pengaruh antara pemahaman terhadap penerapan sistem resi gudang dengan hasil nilai t hitung sebesar 7,881 > t-tabel 1,967 dan nilai signifikan yaitu sebesar 0,000< 0,05 Sehingga $\mathrm{H} 0$ ditolak dan Ha diterima. Artinya ada pengaruh antara pemahaman terhadap penerapan sistem resi gudang.

Sedangkan pengaruh minat terhadap penerapan sistem resi gudang di provinsi Bangka Belitung berdasarkan hasil perhitungan diperoleh $\mathrm{t}$ hitung sebesar 9,802 > t-tabel 1,967 dan nilai signifikan yaitu sebesar $0,000<0,05$. Sehingga H0 ditolak dan Ha diterima. Artinya ada pengaruh antara minat terhadap penerapan sistem resi gudang.

Dari hasil penelitian tersebut di ketahui bahwa terdapat hubungan atau pengaruh yang positif antara pemahaman dan minat terhadap penerapan sistem resi gudang yang berada di provinsi Bangka Belitung, hal ini menunjukkan bahwa potensi terhadap resi gudang yang ada di Bangka Belitung sangat baik dan akan dapat berkembang kalau dilaksanakan semaksimal mungkin dan masyarakat memberikan kontribusi dengan cara memanfaatkan produk layanan yang ada dalam resi gudang itu sendiri sehingga memberikan efek yang posistif

\footnotetext{
${ }^{2}$ Badan Pusat Statistik (BPS), Hasil Survei Pertanian Antar Sensus (SUTAS) 2018, (Jakarta: Badan Pusat Statistk, 2018), hal, 1

${ }^{3}$ Ashari, Potensi Dan Kendala Sistem Resi Gudang (Srg) Untuk Mendukung Pembiayaan Usaha Pertanian Di Indonesia Forum Penelitian Agro Ekonomi,Volume $29 \quad$ No. 2, Desember 2011 : 129-143, http://ejurnal.litbang.pertanian.go.id/index.php/fae/article/view/3898/3240
} 
terhadap pelaku di sektor pertanian yang ada di provinsi Bangka Belitung.

Hasil penelitian ini sejalan dengan apa yang di sampaikam Sadaristuwati (2008) yang dikutiop oleh Ashari, RG memiliki posisi yang penting dalam upaya meningkatkan kesejahteraan pelaku usaha di sektor pertanian dengan argumentasi sebagai berikut: (a) RG merupakan salah satu bentuk sistem tunda jual yang menjadi alternatif dalam meningkatkan nilai tukar petani, (b) Di era perdagangan bebas, RGsangat diperlukan untuk membentuk petani menjadi petani pengusaha dan petani mandiri,dan (c) SRG bisa memangkas pola perdagangan komoditas pertanian sehingga petani bisa mendapatkan peningkatan harga jual komodi.

Selanjutnya, masih menurut Sadaristuwati (2008) keberadaan SRG tidakhanya bermanfaat bagi kalangan petani tetapijuga pelaku ekonomi lainnya seperti duniaperbankan, pelaku usaha dan serta bagipemerintah. Di antara manfaat SRG tersebutadalah: (1) Ikut menjaga kestabilan danketerkendalian harga komoditas, (2) Memberikan jaminan modal produksi karenaadanya pembiayaan dari lembaga keuangan,(3) Keleluasaan penyaluran kredit bagiperbankan yang minim risiko, (4) Ada jaminanketersediaan barang, (6) Ikut menjaga stoknasional dalam rangka menjaga ketahanandan ketersediaan pangan nasional, (7) Lalulintas perdagangan komoditas menjadi lebihterpantau, (8) Bisa menjamin ketersediaanbahan baku industri, khususnya agroindustri,(9) Mampu melakukan efisiensi baiklogistikmaupun distribusi, (10) Dapat memberikankontribusi fiskal kepada pemerintah, dan (11) Mendorong tumbuhnya industri pergudangandan bidang usaha yang terkait dengan SRG lainnya.

\section{Kesimpulan}

Berdasarkan pemaparan data dan pembahasan pada bab IV maka kesimpulan dari penelitian ini yaitu:

1. Pemahaman masyarakat petani lada provinsi Kepulauan Bangka Belitung terhadap sistim resi gudang yang ada di provinsi Bangka Belitung adalah tergolong rendah, hal ini dilihat dengan hasil jawaban dari angket yang telah disebarkan kepada responden yang mewakili dari masing-masing kabupaten. Terdapat $70,3 \%$ (279 responden) tingkat pemahamannya tergolong rendah, 27,5\% (109 responden) tingkat pemahamannya sedang dan 2,3\% (9 responden) tingkat pemahaman yang masuk kategori tinggi. Begitu juga dengan minat petani lada Bangka Belitung terhadap penerapan sistem resi gudang juga tergolong rendah, dari 397 responden sebanyak 58,7 \% (233 responden) tergolong rendah, 34,5\% (137 responden) tingkat minatnya sedang dan 6,8 \% (27 responden) yang masuk kategori minat yang tinggi.

2. Pengaruh pemahaman terhadap penerapan sistem resi gudang yang ada di provinsi Bangka Belitung yaitu terdapat pengaruh positif dan signifikan, berdasarkan hasil pengolahan data dan pembahasan di ketahui terdapat pengaruh antara pemahaman terhadap penerapan sistem resi gudang berdasarkan hasil perhitungan diperoleh $\mathrm{t}$ hitung sebesar 7,881 > t-tabel 1,967 dan nilai signifikan yaitu sebesar $0,000<$ 0,05. Sehingga H0 ditolak dan Ha diterima. Artinya terdapat pengaruh antara pemahaman terhadap penerapan sistem resi gudang. Sedangkan pengaruh minat terhadap penerapan sistem resi gudang, Berdasarkan hasil pengolahan data dan pembahasan diketahui bahwa terdapat pengaruh antara minat terhadap penerapan sistem resi gudang berdasarkan perhitungan diperoleh $t$ hitung sebesar 9,802 $>\mathrm{t}$-tabel 1,967 dan nilai signifikan yaitu sebesar $0,000<0,05$. Sehingga HO ditolak dan Ha diterima. Artinya ada pengaruh antara minat terhadap penerapan sistem resi gudang.

\section{Daftar Pustaka}

Anggun Novita Sari \& Yuliawati. Faktor Yang Mempengaruhi Respon Petani Garam Tentang Sistem Resi Gudang Di Desa Raci Kecamatan Batangan. Journal on Socio-Economics of Agriculture and Agribusiness Vol.13 No.1, 28 Februari 2019, https://ojs.unud.ac.id/index.php/soca

Achmad Fachruddin, Lestari Rahayu. 2017. Evaluasi Prasyarat Keberhasilan Sistem Resi Gudang di Kabupaten Bantul, Journal of Agribusiness and Rural Development Research Vol. 3 No. 2.

Abbdul Syani. 2012. Sosiologi Skematika, Teori, dan Terapan. Jakarta: PT Bumi Aksara.

Budhi Waskito dkk. 2016. Konsistensi Antara Sikap Dan Perilaku Adopsi Petani Padi Terhadap Program Inovasi Sistem Resi Gudang, Sosiohumaniora, Volume 18 No. 3 Nopember $2016: 197-206$.

Cholid Narbuko \& Abu Achmadi. 1999. Metodologi Penelitian. Jakarta: PT Bumi Aksara, 1999.

Iskandarwasid \& Dadang Sunendar. 2011. Strategi Pembelajaran Bahasa. Bandung: Rosda. 
Muhammad Fathurrohman \& Sulistyorini. 2012. Belajar dan Pembelajaran. Yogyakarta: Teras.

Muhammad. 2008. Metodologi Penelitian Ekonomi Islam, Pendekatan Kuantitatif. Jakarta: Rajawali Pers.

Mahfud S. 2001. Pengantar Psikologi Pedidikan. Surabaya: PT. Bina Ilmu, Cetakan 4.

Nana Sudjana. 1995. Penilaian Hasil Proses Belajar Mengajar. Bandung: PT. Remaja Rosdakarya.

Soleman B. Taneko. 1993. Struktur dan Proses Sosial; Suatu Pengantar Sosiologi Pembangunan. Jakarta: PT Raja Grafindo Persada.

Yunita Resmi dkk. 2017. Kajian Peningkatan Pemanfaatan Sistem Resi Gudang Pilot Project Di Kabupaten Kuningan, Jawa Barat (Komoditas Gabah) Dan Konawe Selatan, Sulawesi Tenggara (Komoditas Kakao), Jakarta: Bank Indonesia.

Sugiyono. 2012. Metode Penelitian Bisnis. Bandung: Alfabeta.

Suharsini Arikunto. 2010. Prosedur Penelitan, Suatu Pendekatan Praktik. Jakarta: Rineka Cipta.

WJS. Poerwodarminto. 1984. Kamus Umum Bahasa Indonesia. Jakarta: Balai Pustaka.

Wowo Sunaryo Kuswana. 2012. Taksonomi Kognitif. Bandung: PT Remaja Rosdakarya. 